\title{
The Impact of Women's Education on Fertility In Latin America: Searching for Explanations
}

By Teresa Castro Martín and Fátima Juárez

$\overline{\text { According to data from Demographic and Health Surveys for nine Latin American countries, }}$ women with no education have large families of 6-7 children, whereas better educated women have family sizes of 2-3 children, analogous to those of women in the developed world. Despite these wide differentials in actual fertility, desired family size is surprisingly homogeneous throughout the educational spectrum. While the least educated and the best educated women share the small family norm, the gap in contraceptive prevalence between the two groups ranges from 20-50 percentage points. Better educated women have broader knowledge, higher socioeconomic status and less fatalistic attitudes toward reproduction than do less educated women. Results of a regression analysis indicate that these cognitive, economic and attitudinal assets mediate the influence of schooling on reproductive behavior and partly explain the wide fertility gap between educational strata. ～(International Family Planning Perspectives, 21:52-57 \& 80, 1995)

E ducation has long been recognized as a crucial factor influencing women's childbearing patterns; an extensive demographic literature is devoted to examining the role of female education in promoting sustained fertility decline. ${ }^{1}$ The accumulated evidence provides a compelling rationale for focusing on increased investment in education and the elimination of institutional and cultural barriers to women's schooling in policies aimed at promoting development and reducing fertility. ${ }^{2}$

Although the association between education and fertility was a constant theme in the early literature, the availability of data for the large number of countries that participated in the World Fertility Surveys (WFS) in the 1970s considerably improved our understanding of the relationship. The documentation of empirical patterns for a

Teresa Castro Martín is a population affairs officer at the Population Division, United Nations, and Fátima Juárez is a senior research fellow at the Centre for Population Studies, London School of Hygiene and Tropical Medicine. An earlier version of this article was presented at the International Population Conference of the International Union for the Scientific Study of Population, Montreal, Aug. 24-Sept. 1, 1993, and as a Demographic and Health Surveys Working Paper. The views presented in this article are those of the authors and do not necessarily reflect those of the United Nations. wide variety of settings inspired increasingly complex views: Demographers no longer regarded the impact of education on fertility as automatic, but as conditioned by the level of development, social organization, gender stratification and cultural milieu of the surrounding society.

This new awareness of the complexity of the relationship was accompanied by a shift in the focus of research, in which the earlier emphasis on statistical associations was replaced by an interest in exploring the processes underlying the impact of education on reproductive behavior. In the search for such mediating mechanisms, most of the attention was directed to the proximate determinants of fertility, a legitimate focus given the importance of biological factors in the reproductive process. However, this focus somehow distorted the original goal of understanding the education-fertility relationship in all its complexity and richness. Ultimately, one has to go outside the biological realm to search for explanations for the impact of education on both fertility and its proximate determinants.

Regardless of the approach followed, female education has become an essential component of fertility analysis. Information on schooling is routinely collected in all demographic surveys, and educational at- tainment is a standard criterion used to examine fertility differentials. However, our very familiarity with education as an "independent variable" means that its significance is sometimes taken for granted. The study we discuss in this article provides some insight on what education means to women, in terms of cognitive, economic and normative assets. First, we examine recent educational levels and trends among Latin American women and present empirical evidence on the relationship between education and fertility in the Latin American context. Then we explore how the early experience of schooling transforms a woman's adult world, and link these changes to her reproductive behavior.

\section{Conceptual Framework}

At the macrosocial level, education has been used as an indicator of socioeconomic development in structural explanations of the demographic transition. More recently, it has been identified as a catalyst of "modernization" in innovationdiffusion theories. ${ }^{3}$ At the microsocial level, educated women are usually portrayed as "forerunners" of the fertility transition, that is, as pioneers of smaller families. Given the difficulty of collecting data on income, occupation or social status in demographic surveys, education is typically used as an index of socioeconomic status and as a surrogate for hardto-measure concepts, such as opportunity costs. Moreover, education is frequently the only available indicator for the more comprehensive concept of women's status, which positions women vis-à-vis men in both the family and society. ${ }^{4}$ This wide range of concepts for which education serves as a proxy reflects the multifaceted nature of the educational experience.

The sociology of education literature has drawn attention to various relevant features of the schooling experience. Some perspectives have highlighted the role of 
the school in knowledge transmission and cognitive development, while others have emphasized education as a factor of production that generates wealth. Another focus has been the social organization of schooling and its socialization functions. Inspired by these broad approaches, we examine the following three key dimensions of education and subsequently explore their implications for fertility behavior.

-Education as a "source" of knowledge. Knowledge transmission is probably the school's most explicit goal. Schooling imparts literacy skills, enables pupils to process a wide range of information, and stimulates cognitive changes that shape an individual's interaction with the surrounding world.

-Education as a "vehicle" of socioeconomic advancement. Education not only enhances cognitive abilities, it opens up economic opportunities and social mobility. In most societies, educational credentials are the primary criteria for entry into formal employment and for sorting individuals into the hierarchy of occupations.

-Education as a "transformer" of attitudes. Schooling's role in attitude formation goes far beyond the enhancement of conceptual reasoning and may lead to crucial transformations in aspirations and, eventual$1 y$, to questioning traditional beliefs and authority structures. ${ }^{5}$

We can assume that these three dimensions of education have an impact on women's reproductive desires and behavior. First, the impact of knowledge on fertility is clear in that literacy conditions access to information and is therefore instrumental to informed fertility choices. Furthermore, schooling increases reliance on scientific explanations to make sense of the world and provides greater awareness of alternative lifestyles.

It is illusory to think that women can gain control over their fertility without learning first about their bodies in relation to sex, reproduction and health. The knowledge schooling imparts in these areas, even if marginal in the formal curriculum, may be crucial to the successful use of contraception. The school experience also provides women with greater competence to interact with complex institutions, maximizing their ability to benefit from a range of services, including family planning.

Second, the impact of socioeconomic status on fertility is another factor that explains the negative association between education and fertility. In Latin America, as in many developing societies where the gap between affluent and deprived groups is wide, access to higher education is largely deter- mined by social origin. The observed disparity in reproductive behavior among educational strata, thus, may be partly a reflection of this polarized social structure. ${ }^{6}$

Educational attainment is linked to wealth and hence to the ability to "afford" more children but, more importantly, education is associated with greater perceived costs of children. Higher standard-of-living goals and higher educational aspirations for children usually lead to the decision to have a small family so that more resources can be allocated to each child. ${ }^{7}$ Also, education raises the opportunity costs of children by enhancing women's opportunities to pursue wage-earning activities, which are likely to compete with domestic and childrearing responsibilities.

Third, there are abundant indications that the influence of education on fertility can be partly traced to the impact of attitudes on fertility. Various studies have shown that the impact of female schooling on childbearing cannot be simply reduced to socioeconomic aspects, such as family income, husband's education or husband's occupation. ${ }^{8}$ With the increasing recognition of reproductive behavior as normatively bounded, ${ }^{9}$ schooling has come to be regarded as a decisive stimulus in the shift from a traditional value scheme (where major decisions, such as the number of children, are routinely left to fate or God) to a value system where the belief in a controllable destiny also applies to childbearing. Education also imparts a sense of trust in science and technology, which is indispensable for daily use of modern contraception.

In addition, education induces crucial transformations in the locus of reproductive and contraceptive decisions-the family. As some have argued, by fostering a nuclear family in which spouses share more emotional intimacy and have more egalitarian relationships, education may indirectly facilitate the use of contraception. Another aspect is the style of mother-child interaction: By redefining the maternal role as more time intensive, education can act as an important deterrent to high fertility. ${ }^{10}$

In sum, the school as a social institution provides general and practical knowledge, credentials for employment, an expanded social network and socialization in modern values. The cognitive, economic and attitudinal assets acquired during the "formative" period will differ with the duration of attendance and type of school as well as with the quality and style of instruction, but they will retain their influence throughout a woman's lifetime.

\section{Data}

Our analysis is based on data from the nine Latin American countries that participated in the first round of the Demographic and Health Surveys (DHS), which were fielded in the mid- to late-1980s. All of the surveys included women of reproductive age (usually ages 15-49, but 15-44 in Brazil and Guatemala), regardless of marital status. The DHS are aimed primarily at collecting detailed data on reproductive histories and the proximate determinants of fertility, such as contraceptive use. As such, they provide only general information on socioeconomic factors and just hints of the ideological and cultural context; the available data, thus, impose major constraints on the kind of analysis we are able to conduct. Education is measured, following the usual convention, by length of school attendance. Regrettably, information on other influential aspects of the schooling experience, such as its intensity, quality, content and the style of instruction, are not available.

\section{Levels and Trends}

Within the developing world, Latin America ranks relatively high in educational achievement. The efforts aimed at eliminating illiteracy have been quite successful, and primary schooling, though not universal, is widespread. However, the region is far from homogeneous, and a country's level of socioeconomic development continues to influence the availability of educational resources and women's access to them.

Table 1 (page 54) presents several indicators of women's educational attainment in the nine Latin American countries under consideration. Guatemala, in which $42 \%$ of the women interviewed lack formal schooling, is at the low end of the educational spectrum. Educational deprivation is also evident in El Salvador and Bolivia, where approximately one-fifth of the sample has never attended school. The rest of the countries display more favorable educational conditions, with most women having attended school, although less than one-third have completed 10 or more years of schooling.

From a worldwide perspective, the gender gap in educational attainment in Latin America is fairly narrow. The data on enrollment ratios in Table 1 suggest no obvious gender-based differential in access to educational resources. While rates of enrollment decline at higher levels of schooling among women, the same can be observed for men. Women are substantially underrepresented in secondary education 


\begin{tabular}{|c|c|c|c|c|c|c|c|c|c|c|c|c|c|c|c|c|}
\hline \multirow{3}{*}{$\begin{array}{l}\text { Country and } \\
\text { year of DHS }\end{array}$} & \multicolumn{6}{|c|}{ Years of schooling (\% distribution) } & \multicolumn{4}{|c|}{ Gross enrollment ratios ${ }^{*}$} & \multicolumn{4}{|c|}{ Mean years of schooling } & \multicolumn{2}{|c|}{$\%$ literate } \\
\hline & \multirow[t]{2}{*}{0} & \multirow[t]{2}{*}{$1-3$} & \multirow[t]{2}{*}{$4-6$} & \multirow[t]{2}{*}{$7-9$} & \multirow[t]{2}{*}{$\geq 10$} & \multirow[t]{2}{*}{ Total } & \multicolumn{2}{|c|}{ Primary } & \multicolumn{2}{|c|}{ Secondary } & \multicolumn{2}{|c|}{ Survey } & \multicolumn{2}{|c|}{ Age-group } & \multirow{2}{*}{$\begin{array}{l}\text { Ages } \\
15-19\end{array}$} & \multirow{2}{*}{$\begin{array}{l}\text { Ages } \\
40-44\end{array}$} \\
\hline & & & & & & & Male & Female & Male & Female & DHS & WFSt & $20-24$ & $40-44$ & & \\
\hline Bolivia (1989) & 17.4 & 21.6 & 19.9 & 15.4 & 25.7 & 100.0 & 97 & 85 & 40 & 35 & 5.9 & $\mathrm{u}$ & 7.2 & 4.3 & 93.2 & 45.3 \\
\hline Brazil (1986) & 7.4 & 22.3 & 31.6 & 16.0 & 22.6 & 100.0 & 101 & 97 & 31 & 36 & 5.9 & u & 6.6 & 4.4 & 93.2 & 78.4 \\
\hline Colombia (1986) & 6.9 & 23.9 & 31.3 & 21.0 & 16.8 & 100.0 & 112 & 115 & 55 & 56 & 5.8 & 4.4 & 7.0 & 3.7 & 96.3 & 80.6 \\
\hline Dom. Rep. (1986) & 5.9 & 20.9 & 24.7 & 21.0 & 27.6 & 100.0 & 124 & 129 & 44 & 57 & 6.8 & 4.6 & 8.2 & 4.5 & 91.7 & 71.6 \\
\hline Ecuador (1987) & 7.8 & 14.8 & 32.7 & 16.1 & 28.6 & 100.0 & 118 & 116 & 55 & 57 & 7.1 & 5.7 & 8.3 & 5.4 & 95.5 & 73.9 \\
\hline El Salvador (1985) & 21.3 & 24.6 & 24.6 & 13.4 & 16.0 & 100.0 & 77 & 81 & 27 & 30 & 4.8 & u & 5.9 & 2.9 & 86.5 & 61.2 \\
\hline Guatemala (1987) & 41.7 & 24.1 & 19.6 & 6.2 & 8.4 & 100.0 & 77 & 65 & 50 & 17 & 3.9 & $u$ & 3.7 & 2.1 & 72.5 & 45.5 \\
\hline Mexico (1987) & 11.6 & 16.6 & 31.4 & 26.4 & 14.0 & 100.0 & 119 & 116 & 54 & 53 & 6.2 & 4.0 & 7.5 & 4.1 & 94.1 & 69.5 \\
\hline Peru (1986) & 10.9 & 17.8 & 24.3 & 17.0 & 29.9 & 100.0 & 125 & 120 & 68 & 61 & 5.4 & 3.7 & 7.6 & 4.1 & 93.7 & 63.1 \\
\hline
\end{tabular}

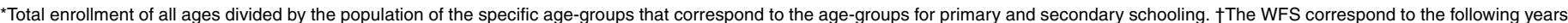

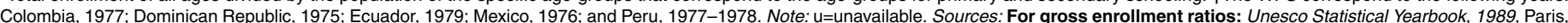
1989; all other indicators: DHS and WFS individual recode files.

only in Guatemala. However, this apparent gender balance in the region should be interpreted prudently, since enrollment figures do not capture the entire reality of education. Drop-out rates, quality of instruction* and the orientation toward fields of study may well differ between men and women.

In the last few decades, the educational attainment of Latin American women has substantially improved. The reduction of illiteracy and the progress toward universal primary schooling have been remarkable achievements, especially given the unfavorable economic situation. Table 1 also shows that for the five countries for which both DHS and WFS data are available, female education improved substantially in the decade between the two surveys: The mean duration of school attendance among women increased by 1.4 years in Colombia and Ecuador, by 1.7 years in Peru, by 2.2 years in the Dominican Republic and by 3.4 years in Mexico.

National averages tend to underestimate the magnitude of recent change, while a comparison of the educational attainment among older and younger cohorts provides a more meaningful indication. Contrasting the average schooling of 40-44-year-old women with that of 20-24-year-olds reveals an even greater improvement: Younger women received approximately three more years of school-

\footnotetext{
*Five of the countries examined have primary school enrollment ratios of more than 100 , suggesting that some children remain in the school system beyond the corresponding ages for grade level. Such pupils reflect a pattern of late entry into school or a high rate of repetition, both signs of deficient quality in education. Latin America currently has grade repetition rates that are among the highest in the world. (See: Economic Commission for Latin America and the Caribbean, "The Impact of Changes on Latin American and Caribbean Women: Education, Knowledge and Demographic Trends," discussion note prepared for the United Nations Expert Group Meeting on Population and Women, Gaborone, Botswana, June 22-26, 1992.)
}

ing than older cohorts in each country except for Guatemala and Brazil, where generational gains are closer to two years.

Similarly, comparing the literacy status of 40-44-year-old women with that of 15-19-year-olds reveals that, with the exceptions of El Salvador and Guatemala, the remaining seven countries have been successful in nearly eradicating female illiteracy: Over $90 \%$ of young women are literate and attend school for at least six years (the usual duration of primary school). In Guatemala, however, more than one-quarter of young women still lack literacy skills, and in El Salvador, roughly one-seventh cannot read or write.

\section{The Relationship}

According to earlier comparative studies, Latin America stands out as the region where the education-fertility relationship is strongest. ${ }^{11}$ Data in Table 2 confirm wide fertility differentials among educational groups. The gap in the total fertility rate (TFR) between the most and least educated women ranges from 3.2 children in the Dominican Republic to 4.9 children in Peru.

These large fertility differentials reveal a highly polarized society in which socially distant groups follow very different reproductive strategies. ${ }^{12}$ In fact, the lower and upper classes in Latin America can be regarded as two subsocieties at different stages of the fertility transition: Poorly educated women have fertility levels typical of pretransitional societies, from six to seven children, whereas better educated women have family sizes analogous to those in the developed world, from two to three children.

The data on desired family size reveal that preferences do not differ much by educational attainment, once age and parity are taken into account. Fertility norms are surprisingly homogeneous, with desired family size varying by only one child or less. Thus, poorly educated women share the same small family norm as educated women, but they are less successful at implementing it.

In contrast with the observed affinity in fertility preferences, contraceptive practices vary widely according to education. ${ }^{13}$ Table 2 shows that the gap in contraceptive prevalence between the least and most educated women ranges from approximately 20 percentage points in Colombia and the Dominican Republic to more than 40 percentage points in Bolivia, Ecuador, Guatemala, Mexico and Peru. In general, the lower the national level of contraceptive prevalence, the larger the gap in contraceptive behavior between poorly and better educated women.

\section{Exploring the Links \\ Indicators and Methods}

Having established the inverse relationship between education and fertility, the next logical step is to inquire about the channels through which this relationship operates. In previous studies, most of the attention was directed to the impact of education on reproductive behavior through the proximate determinants of fertility, particularly marriage timing, breastfeeding duration and contraceptive use. More subtle mechanisms of operation, such as women's expectations from family life, spouse selection, patterns of conjugal interaction, power relationships or women's sense of control over their body and destiny, have often been overlooked.

One of the main reasons for this oversight is that standard demographic surveys do not collect such social and psychosocial data, and qualitative data in general are scarce. However, available survey information can provide some insight into the changes that education triggers in women's lives. Specifically, the DHS data include several indicators of the three broad categories of educational assets that we outlined earlier: 
knowledge - data on exposure to mass media, awareness of sources of modern contraception, and understanding of the ovulatory cycle; socioeconomic status-data on husband's educational level, urban or rural residence, and ownership of household appliances; and attitudes - evidence of fatalism (data on nonuse of contraception when no additional birth is wanted) and the degree of control over the reproductive process (data on parity at first use of contraception). Because cross-tabulations of nine countries and multiple indicators would result in a cumbersome matrix, we present the results for only three countries, which are positioned at different stages of the fertility transition-Colombia, with a TFR of 3.3 children per woman; Ecuador, with a TFR of 4.3; and Guatemala, with a TFR of 5.6.

First we describe how educated and noneducated women differ in terms of knowledge, socioeconomic status and attitudes, as well as their family formation and employment profiles. Next, we examine the mediating role of these cognitive, economic and attitudinal factors in a regression analysis by comparing the impact of schooling on marital fertility, before and after controls for these educationrelated dimensions.

We are aware that ordinary least squares regression analysis might not be the most appropriate methodological tool for fertility analysis since the assumption of homoscedasticity is violated, as the variance of the dependent variable-children ever born-increases with marital duration. However, we chose a simple and easy-to-interpret model for exploratory purposes. We controlled for marital duration and squared it to allow for different effects at short and long durations. Since tests of statistical significance assume simple random sampling and the DHS surveys are based on complex sample designs involving stratification and clustering, and since the assumption of homoscedasticity is violated, we employed a stringent significance level of $\mathrm{p}<.01$ in the analysis.

\section{Outcomes of Education}

The ways in which women differ in the outlined cognitive, socioeconomic and attitudinal domains according to educational attainment are described in Table 3 (page 56). As previously noted, knowledge is the most direct outcome of education. Schooling not only transmits knowledge as part of its curriculum, but stimulates the acquisition of additional information from other channels. The data on the proportion who listen to radio programs, for instance, suggest that education increases women's exposure to mass media. Mass media can influence fertility attitudes and behavior by publicizing nontraditional life styles, including smaller families, and by creating a climate conducive to behavioral change.

Similarly, as the table shows, knowledge of a source or provider of modern contraception increases significantly with women's education. These data suggest that knowledge of practical matters, such as access to means of fertility control, though not imparted in the school curriculum per se, increases with education. Only in societies that have reached an advanced stage of the fertility transition, such as Colombia, is education not a decisive factor in this matter.

Another facet of knowledge closely connected to fertility is women's understanding of the basic facts of human reproduction. The data in Table 3 reveal that the proportion of women who have an adequate understanding of their reproductive physiology is generally low. Women's ignorance about their bodies obviously hinders successful contraceptive use. Sexual and reproductive health education are usually marginal to the school curriculum; nonetheless, the data suggest that education considerably enhances women's knowledge about their bodies.

With regard to socioeconomic status, the data confirm the expected association between women's education and their socioeconomic position. Better educated women have higher household incomes (as inferred from their husband's educa- tion), tend to reside in urban areas, and have a higher standard of living (as suggested by data on refrigerator ownership).

The third outcome of education, attitudinal change, is always difficult to conceptualize, and even more so to measure. Table 3 presents indicators of two diametrically opposed attitudes toward reproduction-fatalism and control. According to these data, educated women have a less fatalistic approach to life and a higher command over their reproduction. When no additional child is desired, better educated women are more likely than less educated women to find the means to implement their desires. The tendency to plan one's family not only applies to size but to timing, as suggested by the early stage of family formation at which educated women start to regulate their fertility.

The multiplicity of facets in women's lives touched by education encompasses both private and public domains. Table 3 also presents a succinct description of women's family formation and work profiles by education. The data show that women's schedules of family formation, which affect completed lifetime fertility, vary considerably with education: Compared with less educated women, those with more schooling enter into unions later, and these unions are more likely to be formal ones. Educated women also are older when they initiate childbearing, and they are less likely to have a premarital birth than are poorly educated women.

Educated and noneducated women also follow different work paths. Although formal education usually opens up economic opportunities, the labor market is highly sex-segregated in many Latin American countries, and women often become trapped in subsistence-level jobs. Since the available data do not provide details on type of occupation or on whether the respondent is employed in the formal sector, we must be cautious not to equate economic activity with economic independence. However, it is reasonable to assume that women with better education-

\begin{tabular}{|c|c|c|c|c|c|c|c|c|c|c|c|c|c|c|c|c|c|c|}
\hline \multirow[t]{2}{*}{ Country } & \multicolumn{6}{|c|}{ TFR } & \multicolumn{6}{|c|}{ Mean desired family size* } & \multicolumn{6}{|c|}{$\%$ contraceptive prevalence $\dagger$} \\
\hline & All & 0 & $1-3$ & $4-6$ & $7-9$ & $\geq 10$ & All & 0 & $1-3$ & $4-6$ & $7-9$ & $\geq 10$ & All & 0 & $1-3$ & $4-6$ & $7-9$ & $\geq 10$ \\
\hline Bolivia & 5.1 & 6.2 & 6.4 & 5.3 & 4.2 & 2.8 & 2.8 & 2.6 & 2.6 & 2.9 & 2.8 & 3.0 & 30 & 12 & 23 & 31 & 43 & 53 \\
\hline Brazil & 3.7 & 6.7 & 5.2 & 3.4 & 2.8 & 2.2 & 3.0 & 3.0 & 3.1 & 2.9 & 2.9 & 2.9 & 66 & 47 & 59 & 71 & 76 & 73 \\
\hline Colombia & 3.3 & 5.6 & 4.5 & 3.6 & 2.5 & 1.8 & 3.0 & 3.2 & 3.1 & 3.0 & 2.9 & 2.9 & 65 & 53 & 61 & 65 & 73 & 73 \\
\hline Dom. Rep. & 3.8 & 5.8 & 5.0 & 4.4 & 3.5 & 2.6 & 3.6 & 3.6 & 3.7 & 3.5 & 3.5 & 3.5 & 50 & 38 & 47 & 51 & 49 & 57 \\
\hline Ecuador & 4.3 & 6.4 & 6.3 & 4.7 & 3.5 & 2.6 & 3.2 & 3.4 & 3.4 & 3.3 & 3.0 & 3.1 & 44 & 18 & 37 & 43 & 50 & 61 \\
\hline EI Salvador & 4.4 & 6.0 & 5.2 & 3.9 & 3.5 & 2.5 & 3.9 & 4.3 & 4.0 & 3.5 & 3.3 & 3.3 & 47 & 37 & 42 & 55 & 51 & 64 \\
\hline Guatemala & 5.6 & 6.9 & 5.6 & 4.2 & 2.8 & 2.7 & 4.2 & 4.6 & 4.0 & 3.5 & 3.7 & 3.4 & 23 & 10 & 24 & 42 & 60 & 60 \\
\hline Mexico & 4.1 & 6.4 & 6.3 & 4.0 & 2.7 & 2.4 & 3.3 & 4.0 & 3.4 & 3.2 & 3.0 & 2.9 & 53 & 25 & 44 & 58 & 70 & 69 \\
\hline Peru & 4.5 & 7.4 & 6.1 & 4.6 & 3.7 & 2.5 & 2.9 & 3.0 & 3.1 & 2.8 & 2.8 & 2.8 & 46 & 19 & 33 & 46 & 60 & 67 \\
\hline
\end{tabular}

*Adjusted by woman's age and number of living children. $†$ Among currently married women. 


\begin{tabular}{|c|c|c|c|c|c|c|c|c|c|c|c|c|c|c|c|}
\hline \multirow[t]{2}{*}{ Measure } & \multicolumn{5}{|c|}{ Colombia } & \multicolumn{5}{|c|}{ Ecuador } & \multicolumn{5}{|c|}{ Guatemala } \\
\hline & 0 & $1-3$ & $4-6$ & $7-9$ & $\geq 10$ & 0 & $1-3$ & $4-6$ & $7-9$ & $\geq 10$ & 0 & $1-3$ & $4-6$ & $7-9$ & $\geq 10$ \\
\hline $\begin{array}{l}\text { Knowledge } \\
\% \text { listens to radio daily } \\
\% \text { knows source of contraception } \\
\% \text { understands ovulatory cycle }\end{array}$ & $\begin{array}{l}67 \\
96 \\
11\end{array}$ & $\begin{array}{l}79 \\
99 \\
18\end{array}$ & $\begin{array}{l}83 \\
99 \\
30\end{array}$ & $\begin{array}{r}88 \\
100 \\
45\end{array}$ & $\begin{array}{r}88 \\
100 \\
72\end{array}$ & $\begin{array}{r}74 \\
60 \\
7\end{array}$ & $\begin{array}{r}82 \\
79 \\
7\end{array}$ & $\begin{array}{l}88 \\
90 \\
17\end{array}$ & $\begin{array}{l}94 \\
95 \\
33\end{array}$ & $\begin{array}{l}96 \\
99 \\
53\end{array}$ & $\begin{array}{r}44 \\
45 \\
4\end{array}$ & $\begin{array}{r}58 \\
75 \\
8\end{array}$ & $\begin{array}{l}73 \\
93 \\
21\end{array}$ & $\begin{array}{l}80 \\
97 \\
41\end{array}$ & $\begin{array}{r}78 \\
100 \\
53\end{array}$ \\
\hline $\begin{array}{l}\text { Socioeconomic status } \\
\text { Husband's mean yrs. of education } \\
\% \text { living in urban area } \\
\% \text { has refrigerator }\end{array}$ & $\begin{array}{r}2.6 \\
50 \\
20\end{array}$ & $\begin{array}{r}3.4 \\
49 \\
30\end{array}$ & $\begin{array}{r}5.1 \\
70 \\
43\end{array}$ & $\begin{array}{r}7.8 \\
89 \\
67\end{array}$ & $\begin{array}{r}11.1 \\
91 \\
79\end{array}$ & $\begin{array}{r}3.0 \\
28 \\
11\end{array}$ & $\begin{array}{r}4.1 \\
32 \\
22\end{array}$ & $\begin{array}{r}6.1 \\
50 \\
35\end{array}$ & $\begin{array}{r}8.4 \\
74 \\
51\end{array}$ & $\begin{array}{r}12.6 \\
89 \\
76\end{array}$ & $\begin{array}{r}1.5 \\
18 \\
2\end{array}$ & $\begin{array}{r}2.9 \\
26 \\
8\end{array}$ & $\begin{array}{r}5.7 \\
55 \\
20\end{array}$ & $\begin{array}{r}8.6 \\
78 \\
46\end{array}$ & $\begin{array}{r}11.9 \\
87 \\
68\end{array}$ \\
\hline $\begin{array}{l}\text { Attitudes } \\
\% \text { not using contraception } \\
\text { when want no more births }{ }^{*} \\
\text { Mean parity at } 1 \text { st contraceptive use }\end{array}$ & $\begin{array}{r}36 \\
3.8\end{array}$ & $\begin{array}{r}25 \\
2.9\end{array}$ & $\begin{array}{r}22 \\
2.0\end{array}$ & $\begin{array}{r}12 \\
1.3\end{array}$ & $\begin{array}{r}13 \\
0.6\end{array}$ & $\begin{array}{r}71 \\
4.6\end{array}$ & $\begin{array}{r}52 \\
4.0\end{array}$ & $\begin{array}{r}42 \\
2.8\end{array}$ & $\begin{array}{r}37 \\
1.9\end{array}$ & $\begin{array}{r}19 \\
1.3\end{array}$ & $\begin{array}{r}75 \\
3.9\end{array}$ & $\begin{array}{r}54 \\
3.0\end{array}$ & $\begin{array}{r}37 \\
2.1\end{array}$ & $\begin{array}{r}10 \\
1.5\end{array}$ & $\begin{array}{r}17 \\
1.1\end{array}$ \\
\hline $\begin{array}{l}\text { Family formation paths } \\
\text { Mean age at first union } \\
\% \text { in legal union } \\
\% \text { had premarital birth } \ddagger \\
\% \text { had first birth }<18 \text { years } \ddagger\end{array}$ & $\begin{array}{r}17.9 \\
42 \\
21 \\
38\end{array}$ & $\begin{array}{r}18.9 \\
64 \\
15 \\
26\end{array}$ & $\begin{array}{r}19.5 \\
60 \\
15 \\
19\end{array}$ & $\begin{array}{r}19.9 \\
72 \\
11 \\
10\end{array}$ & $\begin{array}{r}21.8 \\
86 \\
5 \\
3\end{array}$ & $\begin{array}{r}18.3 \\
62 \\
24 \\
32\end{array}$ & $\begin{array}{r}18.4 \\
62 \\
15 \\
30\end{array}$ & $\begin{array}{r}18.7 \\
62 \\
12 \\
23\end{array}$ & $\begin{array}{r}18.9 \\
63 \\
10 \\
16\end{array}$ & $\begin{array}{r}21.0 \\
86 \\
5 \\
6\end{array}$ & $\begin{array}{r}17.3 \\
56 \\
7 \\
35\end{array}$ & $\begin{array}{r}17.5 \\
55 \\
9 \\
30\end{array}$ & $\begin{array}{r}18.6 \\
66 \\
9 \\
21\end{array}$ & $\begin{array}{r}19.5 \\
78 \\
6 \\
11\end{array}$ & $\begin{array}{r}21.5 \\
86 \\
5 \\
4\end{array}$ \\
\hline $\begin{array}{l}\text { Working paths } \\
\% \text { worked before marriage } \\
\% \text { kept wages§ } \\
\% \text { worked after marriage }\end{array}$ & $\begin{array}{l}49 \\
30 \\
29\end{array}$ & $\begin{array}{l}46 \\
29 \\
26\end{array}$ & $\begin{array}{l}49 \\
32 \\
30\end{array}$ & $\begin{array}{l}55 \\
33 \\
36\end{array}$ & $\begin{array}{l}62 \\
44 \\
53\end{array}$ & $\begin{array}{l}61 \\
40 \\
46\end{array}$ & $\begin{array}{l}59 \\
38 \\
43\end{array}$ & $\begin{array}{l}54 \\
49 \\
32\end{array}$ & $\begin{array}{l}51 \\
56 \\
40\end{array}$ & $\begin{array}{l}54 \\
62 \\
57\end{array}$ & $\begin{array}{l}34 \\
22 \\
18\end{array}$ & $\begin{array}{l}45 \\
23 \\
24\end{array}$ & $\begin{array}{l}51 \\
24 \\
30\end{array}$ & $\begin{array}{l}53 \\
24 \\
33\end{array}$ & $\begin{array}{l}69 \\
45 \\
57\end{array}$ \\
\hline
\end{tabular}

*Among nonpregnant women only. †Among those who have ever used contraception. $\ddagger$ Among all women aged $20-49$. §Among those who worked before marriage.

al credentials find it easier to get a satisfying and financially rewarding job.

The data in Table 3 show that education is positively associated with the rate of labor force participation before marriage in Colombia and Guatemala, and even more strongly after marriage in all three countries. The data also indicate that, among those who worked before marriage, better educated women were more likely than less educated women to have kept their wages for themselves, which suggests that education enhances women's control over their own incomes.

\section{Mediating Influences}

Table 4 provides the results of the multivariate analysis. The regression coefficients confirm that a woman's schooling influences marital fertility not only independently from her husband's education, but also more strongly. Most of the variables included in the model have a significant effect on cumulative fertility. However, contrary to expectations, the indicators of knowledge show a relatively weak impact on children ever born. The only statistically significant negative coefficients correspond to exposure to mass media (in Ecuador) and to understanding the ovulatory cycle (in Colombia). By contrast, the indicators of socioeconomic status display a strong negative influence on fertility in the three countries examined. The same applies for attitudes, as measured by the early use of contraception. The regression analysis also confirms that older age at first birth and the absence of a premarital birth are conducive to lower fertility. The results are less conclusive regarding the effect of union type. Women in consensual unions display lower fertility only in the case of Guatemala. Concerning women's employment histories, only work activity after marriage appears to have a significant negative effect on marital fertility.

The comparison of Model I (unadjusted) and Model II (adjusted) reveals that the magnitude of the regression coefficients for women's education is considerably reduced after controls are applied, suggesting a relevant mediating effect of the cognitive, economic and attitudinal factors considered, as well as of women's family formation and working paths. However, the coefficients for women's education retained their statistical significance in the multivariate model (except for the higher educational categories in Guatemala). This probably occurred because of the imperfect measurement of the constructs employed, but it may also imply that the effect of education goes beyond the pathways hypothesized.

\section{Discussion and Conclusions}

Although fertility differentials by education have narrowed in Latin America over the past decade, ${ }^{14}$ childbearing patterns among the various educational strata remain disparate, resulting in the coexistence of different fertility regimes within the same society. Our analysis shows that reproductive preferences do not differ much among educational groups, whereas contraceptive behavior differs widely.

Our analysis responds to two key questions-how do the sequelae of early schooling hold throughout adulthood and influence lifetime fertility; and why does schooling, which rarely addresses issues directly relevant to sexual, reproductive and contraceptive behavior, influence women's childbearing patterns so decisively? The educational experience has long-lasting implications for women's lives because education serves as a source of knowledge and cognitive skills; as a resource that enhances economic opportunities and social mobility; and as a socialization process that shapes attitudes, values and aspirations.

The divergence in cognitive, economic and normative assets presumably explains why poorly educated and better educated women lead such different lives. Education also conditions women's choices in the domains of family and work. Since education has such a pervasive effect in shaping the whole spectrum of women's roles, reproductive behavior obviously cannot elude its influence.

Despite the centrality of education in demographic analysis, its significance for women's lives tends to be taken for granted. Also, too little attention has been paid to relevant debates within the sociology of education on the role of the school in individual and social change. ${ }^{15}$ In traditional educational theories, a tacit faith in meritocracy shaped the central theme-the value of education for social mobility. The new sociology of education emerged in the early 1970 s as a critical response. ${ }^{16}$ Challenging the assumption of political neutrality, the proponents of the new sociology of education exposed the complicity of the school system in perpetuating and legitimizing social inequality. Going beyond the notion of schools as mere instruction- 
al sites, theorists developed the concept of the "hidden curriculum," arguing that teaching methods, evaluation criteria and social relationships within the classroom were as influential as the written curriculum. Although some of the most influential writings convey a message of distrust of the socially reformative power of schools, this new perspective also emphasizes the role of education in the development of critical consciousness and emancipatory thinking, and its potential to instigate profound social change. ${ }^{17}$

Although the new sociology of education challenged many of the long-standing assumptions that concerned schooling two decades ago, this literature has had only marginal influence on the treatment of education in population studies. Many of the arguments mentioned merit incorporation into demographic discourse. For instance, by questioning the assumption that schools are class-neutral and gender-neutral institutions, the new sociology of education raises an important issue: If access to education is not truly universal, schools may be merely legitimizing the existing social status quo instead of promoting individual advancement and societal change.

Table 4. Among currently married women, regression coefficients for the effect of women's education on number of children ever born, by variable, according to country

\begin{tabular}{|c|c|c|c|}
\hline Variable & Colombia & Ecuador & Guatemala \\
\hline $\begin{array}{l}\text { Model I: Women's education (una } \\
1-3 \text { years } \\
4-6 \text { years } \\
7-9 \text { years } \\
\geq 10 \text { years }\end{array}$ & $\begin{array}{l}\text { usted) } \\
-0.66^{\star} \\
-1.35^{\star} \\
-1.70^{\star} \\
-1.99^{*}\end{array}$ & $\begin{array}{l}-0.15 \\
-0.83^{\star} \\
-1.30^{\star} \\
-1.74^{\star}\end{array}$ & $\begin{array}{l}-0.27^{\star} \\
-0.76^{\star} \\
-1.06^{\star} \\
-1.10^{\star}\end{array}$ \\
\hline $\begin{array}{l}\text { Model II: Women's education }(\text { ad } \\
1-3 \text { years } \\
4-6 \text { years } \\
\text { 7-9 years } \\
\geq 10 \text { years }\end{array}$ & $\begin{array}{l}\text { ted) } \\
-0.41^{*} \\
-0.76^{*} \\
-0.62^{*} \\
-0.55^{\star}\end{array}$ & $\begin{array}{l}-0.01 \\
-0.44^{\star} \\
-0.55^{\star} \\
-0.51^{\star}\end{array}$ & $\begin{array}{l}-0.14^{\star} \\
-0.31^{\star} \\
-0.19 \\
0.08\end{array}$ \\
\hline $\begin{array}{l}\text { Husband's education } \\
1-3 \text { years } \\
4-6 \text { years } \\
7-9 \text { years } \\
\geq 10 \text { years }\end{array}$ & $\begin{array}{l}-0.23 \\
-0.52^{\star} \\
-0.48^{*} \\
-0.61^{\star}\end{array}$ & $\begin{array}{l}0.01 \\
-0.22 \\
-0.39^{\star} \\
-0.35\end{array}$ & $\begin{array}{l}-0.04 \\
-0.24^{\star} \\
-0.33^{\star} \\
-0.22\end{array}$ \\
\hline $\begin{array}{l}\text { Knowledge } \\
\text { Listens to radio daily } \\
\text { Knows source of contraception } \\
\text { Understands ovulatory cycle }\end{array}$ & $\begin{array}{c}-0.13 \\
0.19 \\
-0.19^{\star}\end{array}$ & $\begin{array}{r}-0.29^{\star} \\
0.45^{\star} \\
-0.10\end{array}$ & $\begin{array}{r}-0.02 \\
0.08 \\
-0.08\end{array}$ \\
\hline $\begin{array}{l}\text { Economic status } \\
\text { Urban residence } \\
\text { Has refrigerator }\end{array}$ & $\begin{array}{l}-0.34^{\star} \\
-0.47^{\star}\end{array}$ & $\begin{array}{l}-0.30^{*} \\
-0.44^{*}\end{array}$ & $\begin{array}{l}-0.22^{*} \\
-0.60^{*}\end{array}$ \\
\hline $\begin{array}{l}\text { Attitudes } \\
\text { Used contraceptive at parity } 0 \text { or } 1\end{array}$ & $-0.56^{\star}$ & $-0.49^{\star}$ & $-0.45^{\star}$ \\
\hline $\begin{array}{l}\text { Family formation paths } \\
\text { Currently cohabiting } \\
\text { Had premarital birth } \\
\text { Had first birth < } 18 \text { yrs. }\end{array}$ & $\begin{array}{r}-0.08 \\
0.73^{\star} \\
0.41^{\star}\end{array}$ & $\begin{array}{r}-0.05 \\
0.84^{\star} \\
0.58^{\star}\end{array}$ & $\begin{array}{r}-0.31^{\star} \\
1.10^{\star} \\
0.52^{\star}\end{array}$ \\
\hline $\begin{array}{l}\text { Working paths } \\
\text { Worked before marriage } \\
\text { Worked after marriage }\end{array}$ & $\begin{array}{l}-0.03 \\
-0.17^{\star}\end{array}$ & $\begin{array}{c}0.07 \\
-0.27^{*}\end{array}$ & $\begin{array}{r}0.17^{*} \\
-0.29^{*}\end{array}$ \\
\hline
\end{tabular}

${ }^{*} p<.01$. Note: Both models control for marital duration. The reference category for education is 0 years. tionships to Fertility and Mortality," The Rockefeller Foundation, New York, 1984; and ——, "The Status of Women: Conceptual and Methodological Issues in Demographic Studies," Sociological Forum, 1:284-300, 1986

5. A. Inkeless, "The School as a Context for Modernization," International Journal of Comparative Sociology 14:163179, 1973; and T. O. Eisemon, "Benefitting from Basic Education: A Review of Research on the Outcomes of Primary Schooling in Developing Countries," Special Studies in Comparative Education, No. 20, Comparative Education Center, State University of New York at Buffalo, 1987.

6. J. Schoemaker, "Social Class as a Determinant of Fertility: The Case of Bolivia," Proceedings of the Demographic and Health Surveys World Conference, Vol. I, Institute for Resource Development (IRD)/Macro International, Columbia, Md. 1991, pp. 73-88; and M. Bronfman et al., "Social Sectors and Reproduction in Mexico," DHS Further Analysis Series, No. 7, The Population Council, New York, 1990.

7. N. Birdsall and S.H. Cochrane, "Education and Parental Decision Making: A Two Generational Approach," in L. Anderson and D. M. Windham, eds., Education and Development, D. C. Heath, Lexington, Mass., 1982, pp. 175-210.

8. G. Rodríguez and J. Cleland, "Socioeconomic Determinants of Marital Fertility in Twenty Countries: A Multivariate Analysis," Record of Proceedings of the World Fertility Survey Conference 1980, Vol. 2, International Statistical Institute, Voorburg, the Netherlands, 1980; J. Cleland and G. Rodríguez, "The Effect of Parental Education on Marital Fertility in Developing Countries," Population Studies, 42:419-442, 1988 and G. Rodríguez and R. Aravena, "Socioeconomic Factors and the Transition to Low Fertility in Less Developed Countries: A Comparative Analysis, Proceedings of the Demographic and Health Surveys World Conference, Vol. I, IRD/Macro International, Columbia, Md., 1991, pp. 39-72.

9. J. Cleland and C. Wilson, "Demand Theories of the Fertility Transition: An Iconoclastic View," Population Studies, 41:5-30, 1987; and R. Lesthaeghe and J. Surkyn, "Cultural Dynamics and Economic Theories of Fertility Change," Population and Development Review, 14:1-46, 1988.

10. R. A. LeVine et al., "Women's Schooling and Child Care in the Demographic Transition: A Mexican Case Study," Population and Development Review, 17:459-496, 1991.

11. United Nations, 1987 , op. cit. (see reference 2); and M. B. Weinberger, "The Relation Between Women's Education and Fertility: Selected Findings from the World Fertility Survey," International Family Planning Perspectives, 13:35-46, 1987.

12. F. Juárez, "Las Estrategias Familiares en América Latina en los Distintos Estadios de la Transición de la Fecundidad," IV Conferencia Latinoamericana de Población: La Transición Demográfica en América Latina y el Caribe, Vol. II, Mexico City, Mar. 23-26, 1993.

13. T. Castro Martín and W. Njogu, "A Decade of Change in Contraceptive Behavior in Latin America: A Multivariate Decomposition Analysis," United Nations Population Bulletin, 36:81-109, 1994.

14. M. B. Weinberger, C. Lloyd and A. Blanc, "Women's Education and Fertility: A Decade of Change in Four Latin American Countries," International Family Planning Perspectives, 15:4-28, 1989.

15. H. A. Giroux, "Introduction," in P. Freire, ed., The Politics of Education: Culture, Power and Liberation, Bergin \& Garvey Publishers, South Hadley, Mass., 1985; R. G. Burgess, Sociology, Education and Schools: An Introduction to the Sociology of Education, Nichols Publishing Company, New York, 1986; and P. Wexler, Social Analysis of Education: After the New Schooling, Routledge and Kegan Paul, New York, 1987.

16. P. Bourdieu and J. Passeron, Reproduction in Education, (continued on page 80)
4. K.O. Mason, "The Status of Women: A Review of Its Rela- 
Women's Education and Fertility... (continued from page 57)

Society and Culture, Sage Publishing, Beverly Hills, 1977; and M.W. Apple, ed., Cultural and Economic Reproduction in Education, Routledge and Kegan Paul, London, 1982.

17. P. Freire and D. Macedo, Literacy: Reading the Word and the World, Bergin \& Garvey Publishers, South Hadley, Mass., 1987.

18. S. Heyneman and D. White, The Quality of Education and Economic Development, The World Bank, Washington, D.C., 1986

\section{Resumen}

De acuerdo con datos recabados por las Encuestas Demográficas y de Salud (EDS) realizadas en nueve países latinoamericanos, las mujeres sin educación tienen familias numerosas, de 6-7 hijos, en tanto que las de mejor nivel educativo tienen 2-3 niños, en forma análoga a la mujer del mundo desarrollado. A pesar de estes grandes diferenciales de fecundidad, el número de hijos deseado es sorpresi- vamente homogéneo a todos los niveles educativos. En tanto que las mujeres de menor y superior nivel educativo tienden a desear familias poco numerosas, la brecha en la prevalencia de uso anticonceptivo entre los dos grupos varía de 20 a 50 puntos porcentuales. Las mujeres de mayor nivel educativo tienen un conocimiento más amplio, una condición socioeconómica superior y actitudes menos fatalísticas hacia la reproducción que las de menor nivel. Los resultados de un análisis de regresión indican que estas características de conocimiento, económicas y de actitud median en la influencia de la escolaridad sobre la conducta reproductiva y en parte explican la gran brecha que existe en la fecundidad entre los estratos educativos, aunque no totalmente.

\section{Résumé}

Selon les données des Enquêtes démographiques et de santé (EDS) de neuf pays d'Amérique latine, les femmes non scolarisées ont des familles nombreuses (6 à 7 enfants), et celles instruites à un plus haut niveau, des familles limitées à 2 ou 3 enfants, comparables à celles des femmes du monde développé. Malgré ce large écart de fécondité effective, le nombre d'enfants désiré paraît étonnamment homogène dans l'ensemble des groupes de scolarisation. Si les femmes les moins instruites et leurs homologues les plus instruites partagent le même désir de famille réduite, l'écart qui les sépare, en termes de prévalence contraceptive, se mesure en valeurs pouvant aller de $20 \%$ à $50 \%$. Les résultats de l'analyse de régression indiquent, parmi les femmes mieux instruites, un niveau de connaissances supérieur, de meilleures conditions socio-économiques et un comportement moins fataliste à l'égard de la procréation. Ces facteurs du savoir, économiques et comportementaux favorisent l'influence de la scolarisation sur les comportements procréateurs et expliquent le vaste écart de fécondité entre les différents niveaux d'instruction; l'effet de l'éducation sur la fécondité des mariages s'inscrit, en partie, sur cette ligne. 